\title{
Small-sided football in schools and leisure-time sport clubs improves physical fitness, health profile, well-being and learning in children
}

\author{
Peter Krustrup, ${ }^{1,2}$ Jiri Dvorak, ${ }^{3,4}$ Jens Bangsbo ${ }^{1}$
}

Small-sided football training is an intense, versatile, enjoyable and social training type of exercise that combines highintensity cardiovascular, endurance and strength training for participants across the lifespan. A mere $2 \times 60$ min weekly training is effective for broad-spectrum prevention and treatment of lifestyle diseases. Our conclusion is based on results of more than 100 scientific articles published since January 2009 in 30 international peer-reviewed journals. ${ }^{1-3}$ This evidence has led senior researchers to conclude in The Lancet that 'there is increasing evidence that sports participation has the potential to improve the health of nations'. ${ }^{4}$ Also, among the available evidence on the health benefits of different sport disciplines for adults, 'The best evidence was found for football and running. These can especially improve cardiovascular and metabolic health'.

\section{FITNESS AND HEALTH EFFECTS OF FOOTBALL FOR CHILDREN}

About one-third of the Football for Health studies have investigated football training in schools and in sports clubs. The conclusions are encouraging: (1) small-sided football training induces high heart rates, a large number of intense actions along with high involvement, technical success rates and training effects for boys and girls irrespective of body mass index, fitness level or prior experience with football; ${ }^{67}$ (2) $98 \%$ of children who are members of football clubs live up to the physical activity recommendation of health authorities and they have stronger bones, less fat and greater aerobic fitness

\footnotetext{
${ }^{1}$ Department of Nutrition, Exercise and Sports, Copenhagen Centre for Team Sport and Health, University of Copenhagen, Copenhagen, Denmark ${ }^{2}$ Sport and Health Sciences, College of Life and Environmental Sciences, University of Exeter, Exeter, UK; ${ }^{3}$ F-MARC, Zurich, Switzerland; ${ }^{4}$ Schulthess Klinik, Zurich, Switzerland

Correspondence to Professor Peter Krustrup, Department of Nutrition, Exercise and Sports, Copenhagen Centre for Team Sport and Health, University of Copenhagen, Copenhagen 2100 Ø, Denmark; pkrustrup@nexs.ku.dk
}

than non-sport club members ${ }^{7}$ and (3) small-sided school-based football interventions with just $2 \times 30,3 \times 40$ and $2 \times 45$ min weekly games improve bone health, heart health, physical capacity and learning in children aged $8-12$ years. ${ }^{7-10}$

\section{EVIDENCE-BASED FOOTBALL TRAINING CONCEPTS}

The most prominent evidence-based football training concepts for the general population are 'Football Fitness' for untrained healthy adults and adult patient groups, ${ }^{1-3}$ 'FIFA 11 for Health' for schoolchildren aged 10-12 years ${ }^{9}{ }^{10}$ and 'FIT FIRST', that is, 'Frequent Intense Training, Football, Interval Running and Strength Training' for children aged 8-10 years. ${ }^{7} 8$ The 'FIFA 11 for Health' programme has been implemented in 23 countries in Africa, Latin America, the Caribbean, Southeast Asia and Oceania with a positive impact on health knowledge after the 11 -week intervention period, ${ }^{10}$ and it is FIFA's strategy to expand the project to 100 countries over the coming years.

Recently, the 'FIFA 11 for Health' programme was modified for Europe to focus on non-communicable diseases (NCDs) along with high-intensity football-based training consisting of drills and small-sided games. The pilot project in Denmark revealed positive effects on blood pressure, fat percentage, social well-being and health knowledge (relating to physical training, healthy diet, hygiene and mental health), ${ }^{9}{ }^{10}$ and the programme will now be implemented nationwide for 30000 children in 400 Danish schools in collaboration with the Danish Football Association, FIFA and Copenhagen Centre for Team Sport and Health.

\section{THE COPENHAGEN CONSENSUS CONFERENCE 2016}

On 4-7 April 2016, 24 prominent researchers from six countries evaluated the evidence on the effects of physical activity for children in schools and sport clubs. Our special emphasis was on fitness, health profiles, well-being, social inclusion, cognitive function and learning.
The Consensus Statement from this Copenhagen Consensus Conference will be submitted to the British Journal of Sports Medicine.

A similar conference was held in 2012 with physical activity and learning as the main topic. The consensus statements and other outputs from the conference contributed to evidence that led the Danish Government to legislate for longer school days that included an obligatory 45 min of physical activity per school day. In January 2016, the government of Thailand's Ministry of Education and Health launched a campaign with the slogan 'Teach Less, Learn More'. The goal was to free some time and to apply that to physical activity to tackle the increasing rate of NCDs at an early age. The government signed a Memorandum of Understanding with FIFA to implement the 'FIFA 11 for Health' nationwide as part of the long-term government strategy. We hope that the Copenhagen Consensus Conference 2016 and the Consensus Statement can inspire politicians and health policymakers to focus on the fact that physical activity is a cornerstone in the prevention and non-pharmacological treatment of lifestyle diseases.

\section{IMPLEMENTATION OF 'FIFA 11 FOR HEALTH' AND 'FIT FIRST'}

Evidence-based school-based physical activity concepts that reduce the risk of cardiovascular diseases are needed. Recent scientific research shows that 'FIFA 11 for Health' and 'FIT FIRST' are effective and also safe and easy to implement in the European school system. ${ }^{7-10}$ These programmes are taught by schoolteachers, and sessions are short $(2 \times 45$ or $3 \times 40 \mathrm{~min} /$ week) with drills and smallsided games that can be conducted in small areas on a variety of indoor and outdoor surfaces. $^{7-10}$ It is noteworthy that the positive effects on health knowledge, well-being, fitness and health status occur independent of the participant's football experience or skills. ${ }^{7-10}$ Football and other intense sport activities have tremendous effects when implemented in sport clubs and in schools. It is time to implement them on the largest possible scale; locally and globally.

\footnotetext{
Acknowledgements The authors thank the team at the Copenhagen Centre for Team Sport and Health, University of Copenhagen, supported by Nordea-fonden, Denmark, FIFA/F-MARC for continuous intellectual and financial support, as well as more than 200 collaborators in 16 different countries.

Competing interests None declared.

Provenance and peer review Not commissioned; externally peer reviewed.
} 


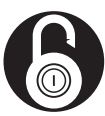

\section{OPEN ACCESS}

Open Access This is an Open Access article distributed in accordance with the Creative Commons Attribution Non Commercial (CC BY-NC 4.0) license, which permits others to distribute, remix, adapt, build upon this work non-commercially, and license their derivative works on different terms, provided the original work is properly cited and the use is noncommercial. See: http://creativecommons.org/licenses/ by-nc/4.0/

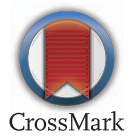

To cite Krustrup P, Dvorak J, Bangsbo J. Br J Sports Med 2016;50:1166-1167.

Accepted 3 April 2016

Published Online First 20 June 2016
Br J Sports Med 2016:50:1166-1167. doi:10.1136/bjsports-2016-096266

\section{REFERENCES}

1 Krustrup P, Nielsen JJ, Krustrup BR, et al. Recreational soccer is an effective health promoting activity for untrained men. Br J Sports Med 2009;43:825-31.

2 Krustrup $\mathrm{P}$, Aagaard $\mathrm{P}$, Nybo L, et al. Recreational football as a health promoting activity: a topical review. Scand J Med Sci Sports 2010;20(Suppl 1):1-13.

3 Bangsbo J, Hansen PR, Dvorak J, et al. Recreational football for disease prevention and treatment in untrained men: a narrative review examining cardiovascular health, lipid profile, body composition, muscle strength and functional capacity. $\mathrm{Br}$ J Sports Med 2015:49:568-76.

4 Khan KM, Thompson AM, Blair SN, et al. Sport and exercise as contributors to the health of nations. Lancet 2012;380:59-64.

5 Oja P, Titze $S$, Kokko S, et al. Health benefits of different sport disciplines for adults: systematic review of observational and intervention studies with meta-analysis. $\mathrm{Br}$ J Sports Med 2015:49:434-40.
6 Bendiksen M, Williams CA, Hornstrup T, et al. Heart rate response and fitness effects of various types of physical education for 8- to 9-year-old schoolchildren. Eur J Sport Sci 2014:14:861-9.

7 Krustrup P, Hansen PR, Nielsen CM, et al. Cardiovascular adaptations to a 10 -wk small-sided school football intervention for 9-10-year-old children. Scand I Med Sci Sports 2014:24:4-9.

8 Larsen MN, Nielsen CM, Helge EW, et al. Positive effects on bone mineralisation and muscular fitness after 10 months of intense school-based physical training for children aged 10-10 years: the FIT FIRST randomised controlled trial. $\mathrm{Br}$ I Sports Med Published Online First: 13 June 2016 doi:10.1136/ bjsports-2016-096219

9 Fuller C, Ørntoft C, Larsen MN, et al. 'FIFA 11 for Health' for Europe. 1: effect on health knowledge and well-being of 10- to 12-year-old Danish school children. Br J Sports Med Published Online First: 29 Apr 2016. doi:10.1136/bjsports-2016-096123

10 Ørntoft C, Fuller CW, Larsen MN, et al. 'FIFA 11 for Health' for Europe. II: effect on health markers and physical fitness in Danish schoolchildren aged 10-12 years. Br I Sports Med Published Online First: 29 Apr 2016. doi:10.1136/bjsports-2016-096124 